CSAGE Publishing, 2021. This paper is not the copy of record and may not exactly replicate the authoritative document published in Group Processes and Intergroup Relations. Please do not copy or cite without author's permission.

Backlash against the \#MeToo movement: How women's voice causes men to feel victimized

\author{
Jaclyn A. Lisnek ${ }^{1}$ \\ Clara L. Wilkins $s^{2,3}$ \\ Megan E. Wilson ${ }^{2}$ \\ Pierce D. Ekstrom ${ }^{4}$ \\ ${ }^{1}$ University of Virginia, ${ }^{2}$ Washington University in St. Louis, ${ }^{3}$ University of Washington, \\ ${ }^{4}$ University of Nebraska - Lincoln
}

Accepted for publication at Group Processes and Intergroup Relations

Author's note: Address correspondence to: Jaclyn A. Lisnek, Department of Psychology, University of Virginia, Charlottesville, VA 22903 [email: jal4kh@ virginia.edu]. The authors thank reviewers for helpful comments on previous drafts. All materials, data and preregistered hypotheses can be found on OSF at the following link: https://osf.io/6gfa2/?view_only=16b4f494b59640b381e8d23ff2230048 


\begin{abstract}
Three studies examined whether perceived increases in women's "voice" (i.e., being heard and taken seriously about sexual assault) contributes to perceptions of bias against men. In Study 1, both men and women who perceived women to have greater voice related to sexual assault perceived greater victimization of men. This relationship was stronger for relatively conservative participants. In Study 2, relatively conservative (but not relatively liberal) participants who read about \#MeToo perceived greater men's victimization than those in the control condition. Study 3 examined responses to perceiving that men are victimized by \#MeToo. For relatively conservative (but not liberal) men, perceptions of men's victimhood lead to less willingness to work alone with a woman and less willingness to combat sexual assault (relative to a control condition). Thus, while the \#MeToo movement brings awareness to issues of sexual assault, it also generates backlash among the more conservative and may accentuate gender disparities.
\end{abstract}




\section{Backlash against the \#MeToo movement: How women's voice causes men to feel victimized}

"It's a very scary time for young men in America, where you can be guilty of something you may not be guilty of."

President Donald Trump (Diamond, 2018)

"If you have a son, make sure you buy him a note pad, a body camera, and a recording device. Get him a battery pack too so he can always protect himself with video evidence of every single encounter he has with a woman. Men aren't safe in America anymore. There is a war on men." Right-wing activist Laura Loomer (North, 2018)

Sexual assault has long been a significant social problem, and although instances in the U.S. have fallen by half in the last two decades (RAINN, n.d.), the statistics remain troubling at best. Nearly half a million Americans are sexually assaulted every year, equivalent to one American being sexually assaulted every 73 seconds (RAINN, n.d.). Although sexual assault affects both men and women, most victims are women (91\%; Rennison, 2002), with one in three women experiencing sexual violence during their lifetime (Division of Violence Prevention, 2010-2012). Moreover, by recent estimates, sexual assault is the most under-reported crime in the country, with nearly $80 \%$ of sexual assault incidents going unreported (Morgan $\&$ Kena, 2018). In 2017, the \#MeToo movement drew unprecedented attention to this under-reported and chronic problem.

While the movement has been celebrated for bringing attention to sexual assault (Easley, 2018), some have responded less favorably - as exemplified in the epigraphs. Although many saw the movement as empowering women, others have tied \#MeToo to the victimization of men. We suggest that some people perceive women's empowerment around sexual assault as a threat to men. The purpose of the current research is to examine whether and for whom this happens. 
We propose that perceived increases in women's "voice" (i.e., being heard and taken seriously about sexual assault) are perceived as threatening to the existing gender hierarchy and thus cause individuals, particularly those who are more politically conservative, to view men as victims. Further, we suggest that perceptions of men's victimization will lead to negative consequences for women.

\section{\#MeToo and Public Reactions to the Movement}

Women's accounts of their experiences with sexual assault are often unheard, dismissed, or challenged outright (Kilpatrick et al., 2007; MacKinnon, 2019; Safronova \& Halleck, 2019; Ullman, 2010). The \#MeToo movement gave women a platform to increase attention to the issue. Tarana Burke first coined the phrase in 2006, but it went viral on the social media platform Twitter in 2017 when actress and activist Alyssa Milano tweeted “\#MeToo" to encourage people to share their stories of sexual assault and highlight the universality of the issue (Pflum, 2018). Since the movement started, the voices of women sharing their experiences with sexual assault have been amplified, and millions of people have shown their support for the movement through tweets, rallies, and other modes of activism (Anderson \& Toor, 2018).

Prominent news outlets have called attention to the tangible consequences the \#MeToo movement has had for alleged perpetrators of sexual assault and harassment. For example, the New York Times reported 201 cases in which men lost their high-status jobs, leadership roles, or contracts due to allegations made public using the \#MeToo hashtag (Carlsen et al., 2018). While coverage like this suggests that the \#MeToo movement helped hold male perpetrators of sexual assault to account, some prominent figures (North, 2018) have argued that the \#MeToo movement might represent a broader threat to men in general—not just those who rape or harass 
women. Citing this perceived threat and concern about false allegations, some perceive that the movement goes too far (Ipsos, 2018).

\section{Backlash against Social Change}

These negative reactions to the \#MeToo movement resemble reactions to other movements that have advocated social change (e.g., the women's suffrage movement, the civil rights movement, the Black Lives Matter movement) (Marshall, 1986; Anderson, 2016). People often resist changes that threaten familiar norms, practices, and hierarchies (e.g. Eidelman \& Crandall, 2012; Jost \& Hunyady, 2005; Sidanius \& Pratto, 1999). Decades of socialpsychological theory and research have attempted to explain this resistance, tracing bias in favor of the status quo to motives to justify the existing social order (Jost \& Banaji, 1994), to believe that the world is fair (Lerner, 1980), to pursue material self-interest (Bobo, 1999; Bobo \& Hutchings, 1996), and to avoid unknown risks (Moshinsky \& Bar-Hillel, 2010). This work has produced important insights, but it yields potentially competing predictions for who is most likely to resist the changes advocated by the \#MeToo movement.

First, some research suggests that group advantage is an important predictor of negative reactions to hierarchy-attenuating social change. That is, those "at the top" defend what they have from those "at the bottom" to protect their group's advantages (Sidanius \& Pratto, 1999). For instance, men endorse hierarchy enhancing beliefs to a greater extent than women because they are more invested in maintaining their position (Mebane et al., 2020). Further, White survey respondents in the U.S. and South Africa resist policies that redistribute resources to disadvantaged racial groups (Bobo, 1999; Dixon et al., 2012), and even men who claim to have positive attitudes toward women often believe that women should live and behave in ways that confine them to subordinate social roles (Dixon et al., 2012; Jackman, 1994). These defensive 
tendencies often intensify when changes to the status quo are made salient. For example, when White Americans who perceive the racial hierarchy as legitimate perceive racial progress, they respond by perceiving discrimination against Whites (Wilkins \& Kaiser, 2014; Wilkins et al., 2017). In a similar vein, when White Americans perceive increasing racial diversity, they become more concerned about anti-White discrimination (Craig \& Richeson, 2017) and express increased pro-White bias (Craig \& Richeson, 2014). Similarly, men who believe their genderbased advantage might be lost report less support for policies intended to reduce gender inequality (Kuchynka et. al, 2018). This research suggests that men, given their relative advantage in society, may respond negatively to the \#MeToo movement to the extent that they perceive it as a potential threat to their social advantage.

Men and women may differ not only in their preferences for group-based hierarchy, but also in their reactions to the \#MeToo movement, given their different experiences with sexual harassment and assault. Nearly one in five women have experienced rape or attempted rape as compared to one in 38 men (Smith et al., 2015), and the vast majority of perpetrators are men (Black et al., 2011). These differing base-rates may play a role in shaping attitudes, such that women may be more likely to see themselves as typical victims and men as typical perpetrators of sexual assault. Given these gendered prototypes of victims and perpetrators, some may perceive the \#MeToo movement as helping women and hurting men, and this may color their reactions to the movement. Lastly, people may view sexual assault or harassment as a women's issue given that most victims of both are women (Kearl, 2018). Together, this evidence suggests that gender may be an important predictor of reactions to the movement.

In contrast, another body of work suggests that resistance to change is not limited to those who benefit from preserving the status quo (Jost \& Hunyady, 2002). For instance, women and 
members of other disadvantaged groups demonstrate favoritism toward members of outgroups when they are high in "system justification" (Jost \& Burgess, 2000). Members of disadvantaged groups sometimes even report attitudes that favor the interests of outgroup members over their own personal material interests (Jost \& Banaji, 1994). Moreover, social dominance orientation suggests a desire for dominance and hierarchy regardless of what that means for one's ingroup (Sidanius et al., 2001); for example, both White and non-White participants penalize Black discrimination claimants to the extent that they are high in SDO (Unzueta et al., 2014; also see Wilkins et al., 2013) even though the discrimination claim might be seen as helping racial minorities (the ingroup for Black participants; see Kaiser et al., 2009). Finally, other research suggests that men and women have similar perceptions of sexual harassment (Goh et al, 2021). These findings suggest that attitudes toward social change may be more closely tied to people's endorsement of ideologies that justify existing social structures than to their own position within the hierarchy (i.e. gender group membership).

In particular, we expect that political conservatism shapes individuals' reactions to the \#MeToo movement in the contemporary United States. Jost and colleagues have argued that contemporary conservatism represents a "system-justifying" ideology in that it reliably predicts negative attitudes toward social change and relatively positive attitudes toward social and economic inequality (Jost et al. 2001; Jost \& Kende, 2020; Jost et al., 2003; Jost et al., 2008). Given the \#MeToo movement's explicit emphasis on furthering egalitarian social change, we would expect conservatives to respond less favorably to the movement than liberals. In this way, the effects of ideology on support for (and opposition to) the \#MeToo movement may closely resemble the effects of ideology on attitudes toward other movements devoted to hierarchyreducing social change. 
In addition, political conservatism specifically predicts the way people think about sexual assault. Conservatism is positively associated with support for alleged perpetrators of sexual assault and negatively associated with perceptions that sexual assault is an important issue (van der Linden \& Panagopulous, 2019). Conservatives are less likely than liberals to believe allegations made by victims of sexual assault (Alter, 2017), and despite evidence that false allegations are rare (between 2 and 10\% of reported cases; Clark \& Lewis, 1977; Ferguson \& Malouff, 2016; Grace et al., 1992), 77\% of Republicans believe false accusations against men are common, compared to $37 \%$ of Democrats (Ipsos, 2018). Conservatives are also more likely than liberals to blame victims for sexual assaults (Lambert \& Raichle, 2000) and penalize women who delay reports of sexual assault (Lucarini et al., 2020). Thus, as a movement that strives both to promote social change and to hold perpetrators of sexual assault and harassment to account, the \#MeToo movement may present both a general threat to conservatives' ideological opposition to social change and a more specific threat to conservatives' particular beliefs about the frequency, importance, and root causes of sexual assault.

In sum, existing evidence suggests that (1) advantaged group members are motivated to protect their advantaged position in society and (2) individuals with hierarchy-enhancing ideologies react negatively to the possibility of hierarchy-attenuating social change. Thus, both gender and political conservatism could predict negative reactions to the \#MeToo movement. Some national polling suggests that of the two, political orientation may be more important; the gap between men's and women's attitudes toward the \#MeToo movement is smaller than that between conservatives' and liberals' attitudes (Ipsos, 2018). Further, when asked if gender equality has gone too far, the political gap was nearly three times that of the gender gap (Horowitz, 2017). While on average women tend to lean more toward the political left than men 
do, there are still many conservative women. For example, $37 \%$ of women who were registered to vote in 2017 identified with or leaned towards the Republican party (Pew Research Center, 2018). And although men have been shown to endorse greater social dominance orientation overall (i.e., greater desire for group-based dominance and hierarchies; Sidanius \& Pratto, 1999), extreme right-wing women have significantly higher SDO than men who belong to left-wing parties (Mebane et al., 2020). That is, the motivation to hold up the gender hierarchy is not unique to men, and therefore, both men and women may actively participate in the backlash against the movement. Meanwhile, political orientation may create a more impermeable boundary between opponents and supporters of the movement, such that liberals (including men) may be more willing to support \#MeToo (Costa et al., 2020). Still, the relative weight of gender and conservatism in this backlash remains an open empirical question.

Regardless of whether gender or political orientation is a greater predictor of \#MeToo backlash, we expect this backlash to manifest in beliefs that the movement unfairly victimizes men. People who justify the system see social change as going "too far" - as making unwarranted, unnecessary, undesirable changes to the status quo that invert rather than eliminate bias, disadvantaging previously dominant groups (e.g. Wilkins \& Kaiser, 2014; Wilkins et al., 2016). The dominant group becomes the victim of change. In the case of sexual assault, men are the dominant group, and are the ones who would "get less" (trust, credibility, status) as a result of the perceived social change that \#MeToo advocates.

\section{Current Research}

The current research examines the relationship between attention to sexual assault (i.e., women's voice and reading about the \#MeToo movement) and perceptions that men are victimized. Study 1 tested this cross-sectionally. Study 2 examined whether there is a causal 
relationship between women's voice and men's victimization. In Study 3, we examined how men's perceptions of victimization affect their intended behavior toward women.

Overall, we hypothesize that perceptions of women's voice - that is, perceptions that women can and do speak out against sexual assault, and that what they say makes some difference - will predict greater perceptions that men are victims, particularly among participants who score higher (vs. lower) on political conservatism. Further, we predict that priming participants with the \#MeToo movement as bringing greater attention to women's sexual assault experiences will cause more conservative (but not more liberal) participants to perceive men as victims. Lastly, we predict that relatively conservative men led to believe that \#MeToo victimizes men will report wanting to distance themselves from women in ways that could hurt women's careers.

\section{Study 1}

Study 1 examined the relationship between perceptions of women's voice and perceptions that men are victimized. Additionally, we tested whether participants' gender and political orientation moderated the relationship. Given existing evidence that political conservatives are more likely to favor the status quo, recent trends in public opinion toward the \#MeToo movement (IPSOS, 2018) and evidence that gender does not moderate perceptions of sexual harassment (Goh et al, 2021), we expected political orientation to be a stronger predictor of perceived men's victimization than participant gender. Furthermore, we hypothesized that among more conservative (but not more liberal) participants, perceptions of women's voice on issues of sexual assault would predict perceived victimization of men. For simplicity, we do not report all measures, however, all study materials, data and syntax can be found here: https://osf.io/6gfa2/?view only=16b4f494b59640b381e8d23ff2230048. 


\section{Method}

\section{Participants}

We recruited 927 participants online through TurkPrime's Mechanical Turk Toolkit in exchange for $\$ 1^{1}$. Data were analyzed for 839 individuals ( $50.5 \%$ women) who remained after removing those who failed attention checks ${ }^{2}$ or those who did not identify as heterosexual ${ }^{3}$ and cisgender. The sample was 71.1\% White, 8.4\% Asian American, 6.8\% African American, 7.5\% Latino/Hispanic American, 0.6\% Native American, 5.3\% multiracial, and 0.4\% other.

Participants' ages ranged from 18 to 81 years $(M=40.07, S D=12.52)$.

\section{Procedure and measures}

After consenting, participants completed measures in the order described below. All items were rated using scales from 1 (strongly disagree) to 7 (strongly agree) unless otherwise noted. See Table 1 for $M s, S D$ s, alphas, and correlations between measures. For preregistration, see here: https://osf.io/m8yex/?view_only=bd1adad7f1514852a97e35d8f142dcc1 and for all Study 1 materials and data, see here: https://osf.io/pq397/?view_only=5fdd3a90d7bb41b1bc5fdfd5dfb908c2.

Men's Victimization. A 4-item composite assessed perceptions that men are victims of false allegations and unfair suspicion of sexual assault. For example, (1) "Men are treated unfairly in cases of sexual assault claims," (2) "Nowadays, men are not able to freely express their romantic desires for women."

Women's Voice. A 6-item composite assessed perceptions of women's voice. Examples include (1) "Women are allowed to freely express their opinions when it comes to issues of sexual assault," and (2) Women's voices are often silenced on issues of sexual assault" (reverse scored). 
Political Orientation. Participants reported their political orientation by responding to the question: "When it comes to politics, do you usually consider yourself to be liberal, conservative, or moderate?" using a scale of 1 (very liberal) to 7 (very conservative). Table 1. Correlations, means, and reliabilities for measures in Study 1.

\begin{tabular}{lcccc} 
Variables & 2 & 3 & $\begin{array}{c}\text { Mean } \\
(\text { SD })\end{array}$ & $\alpha$ \\
\hline $\begin{array}{l}\text { 1) Men's } \\
\text { Victimization }\end{array}$ & $0.44^{* *}$ & $0.44^{* *}$ & 3.54 & 0.92 \\
& & & $(1.72)$ & \\
& & & & \\
2) Women's & - & $0.34^{* *}$ & 4.95 & 0.90 \\
Voice & & & $(1.27)$ & \\
& & & & \\
& & & & \\
3) Political & - & & $(1.79)$ & \\
Orientation & & & & \\
& & & & \\
\hline
\end{tabular}

Note: $* *$ significant at .01 level

\section{Results and Discussion}

\section{Predictors of men's victimization}

To test whether political orientation or gender were stronger predictors of perceived men's victimization, we first used OLS regression to predict perceptions of men's victimization from participants' perceptions of women's voice, political orientation, and gender. Conservatism positively predicted perceived victimization $(b=0.33, p<.001,95 \% \mathrm{CI}[0.27,0.39])$.

Perceptions of women's voice also predicted victimization $(b=0.39, p<.001,95 \% \mathrm{CI}[0.31$, 0.47]). Compared to women, men reported stronger perceptions that men are victims $(b=0.50$, $S E=0.10, t(836)=4.95, p<.001,95 \%$ CI $[0.30,0.70])$. 
To examine whether gender or political orientation accounted for more variance in perceptions of men as victims, we examined each variable's incremental contribution to $R^{2}$ with women's voice, political orientation, and gender in the models. The unique contribution of political orientation (incremental $R^{2}=.10$ ) was larger than that of gender (incremental $R^{2}=.02$ ).

\section{Gender as a moderator}

To determine whether men and women differed in the extent to which they associated women's voice related to sexual assault with men's victimization, we ran a regression using Hayes' PROCESS macro model 1 (Hayes, 2017). Specifically, we regressed participants' perceptions that men are victims on their perceptions of women's voice (mean-centered), their gender $(0=$ men, $1=$ women $)$, and the interaction between these two predictors. Voice and gender did not significantly interact $\left(b_{\text {interaction }}=0.003, p=.98,95 \% \mathrm{CI}[-0.17,0.17]\right)$. Although previous analyses revealed that men tended to perceive men as more victimized than women did, this null interaction coefficient indicates that perceptions of women's voice had the same (positive) effect on perceptions of men's victimization among both men and women participants.

\section{Political orientation as a moderator}

Using PROCESS, we examined political orientation as a moderator of the effect of women's voice on victimization. We regressed participants' perceptions that men are victims on their perceptions of women's voice (mean-centered), their political ideology (mean-centered), and the interaction between these two predictors. The interaction between voice and political orientation was marginally significant $\left(b_{\text {interaction }}=0.04, p=.06,95 \%\right.$ CI $\left.[-0.002,0.08]\right)$.

The model estimates a significant and positive relationship between women's voice and victimization among relatively conservative participants (1 SD above ideology's mean; i.e., 5.47, between "slightly conservative" and "conservative" on our 7-point scale) and among relatively 
liberal participants (1 SD below ideology's mean; i.e., 1.89, approximately "liberal” on our 7point scale). These results are depicted in Figure $1\left(b_{\text {conservative }}=0.52,95 \% \mathrm{CI}[0.40,0.64] ; b_{\text {liberal }}\right.$ $=0.38, p<.001,95 \%$ CI $[0.27,0.48])$. The relationship between perceptions of women's voice and men's victimization was stronger to the extent that participants identified as conservative rather than liberal.

Figure 1. Political orientation moderates the relationship between women's voice and men's victimization for Study 1.

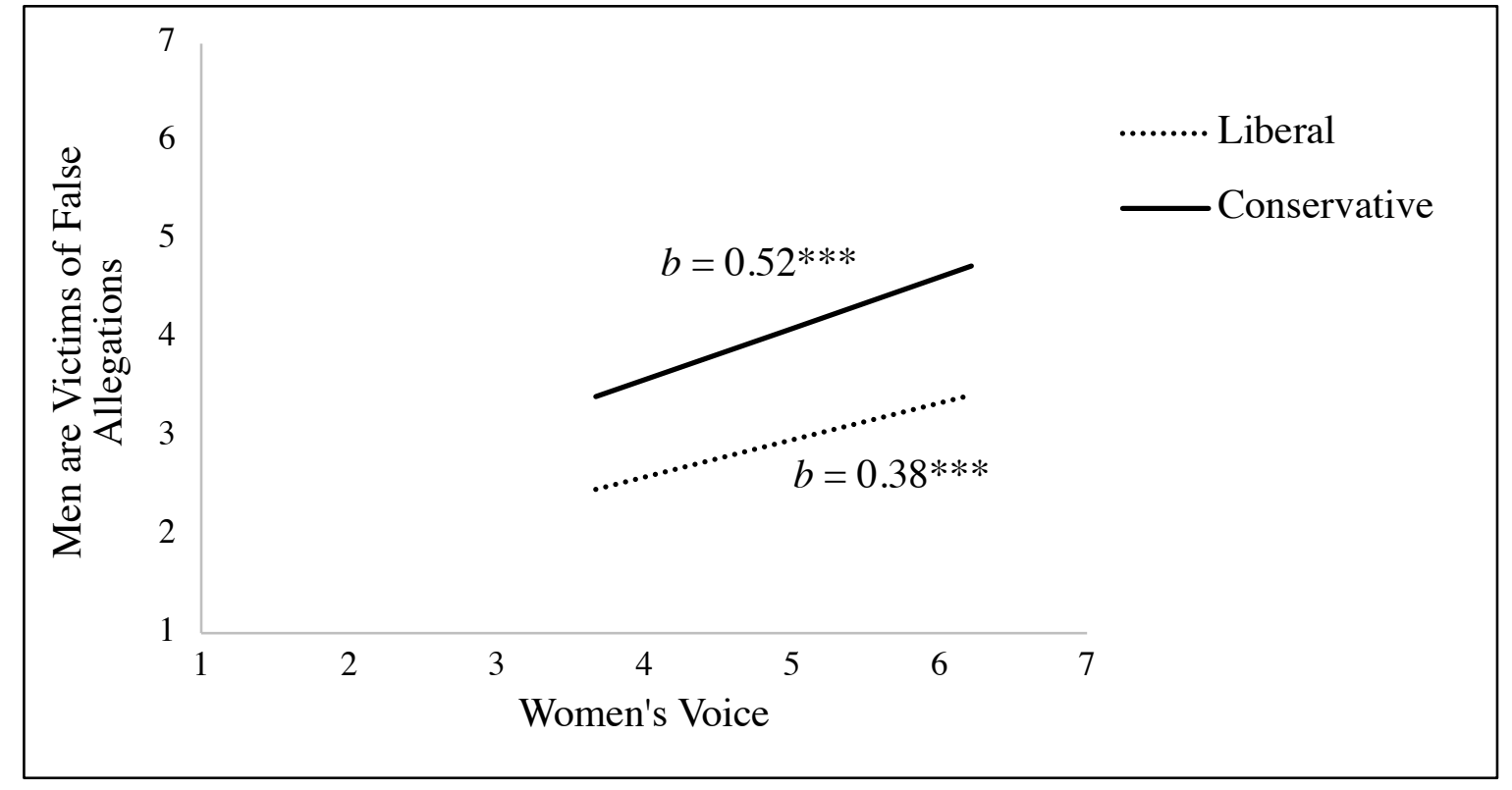

Note: $* * *$ significant at .001 . Coefficients are unstandardized. Variables are not meancentered. Thus, values correspond to the actual points on the scale.

Study 1 tested whether participant gender, political orientation and perceptions of women's voice predict the extent to which participants perceive that men are victimized. As predicted, both political orientation and women's voice significantly predicted perceptions of men's victimization. Additionally, political orientation (but not gender) marginally moderated the relationship between voice and men's victimization such that the relationship was stronger for relatively conservative than for relatively liberal participants. Although our main hypotheses 
were supported, it is unclear from Study 1 whether women's voice causes increased perceptions of victimization, as the evidence is correlational.

\section{Study 2}

Study 2 examined whether perceptions of women's voice cause perceptions that men are victimized by the \#MeToo movement. We hypothesized that participants primed to perceive increased women's voice would report greater victimization of men relative to a control condition. Furthermore, consistent with Study 1, we predicted that the relation between women's voice and men's victimization would be stronger to the extent that participants identified as conservative rather than liberal.

\section{Method}

\section{Participants}

We recruited 117 White ${ }^{4}$ participants online through Amazon's Mechanical Turk in exchange for $\$ 1$. After removing individuals who failed attention checks and who did not identify as heterosexual and cisgender, 96 individuals remained (49\% women). Participants' ages ranged from 19 to 72 years $(M=38.5, S D=11.4)$.

\section{Procedure and measures}

We manipulated women's voice by randomly assigning participants to one of two conditions. In the High Voice condition, they read about the \#MeToo movement and how it has increased reports of sexual assault and attention to sexual assault experiences. For example, participants read about how "women have spoken up about their experiences in unprecedented numbers" and that women are "formally reporting their sexual assault experience to HR and even to law enforcement." In the Control condition participants read about recommendations for giftgiving; the goal was to make gender salient (by discussing gift ideas for men and women) 
without reference to sexual assault or women's voice. For example, participants read about how “access to gift guides has made it much easier for people who don't love searching for gifts to find the perfect present for the men and women in their lives.” Again, we do not report all measures or conditions ${ }^{5}$, however, all study materials, data and syntax could be found here: https://osf.io/9zpx5/?view_only=693aa6c25b874851855d15f3a321593a.

Participants then completed dependent measures.

Men's victimization ${ }^{6}$ is a 5 -item composite. The victimization measure in Study 1 assessed participants' beliefs that men were victimized by spurious allegations of sexual assault. To examine whether women's voice affects perceptions that men are victimized more generally (rather than only by sexual assault allegations), we used a broader measure of men's victimization in Study 2. Items in the broader Study 2 measure included "It's a scary time to be a man in America" and "Men are under attack in America." We present results for the more specific measure in the supplement. See Table 2 for $M s, S D s$, and correlations between measures.

Participants also reported their perceptions of women's voice, and demographics including their political orientation (variables were assessed as in Study 1).

Table 2. Correlations, means, and reliabilities for measures in Study 2.

\begin{tabular}{lcccc} 
Variables & 2 & 3 & $\begin{array}{c}\text { Mean } \\
(\mathrm{SD})\end{array}$ & $\alpha$ \\
\hline $\begin{array}{l}\text { 1) Men's } \\
\text { Victimization }\end{array}$ & $0.43^{* *}$ & $0.67^{* *}$ & $\begin{array}{c}3.14 \\
(1.70)\end{array}$ & 0.94
\end{tabular}

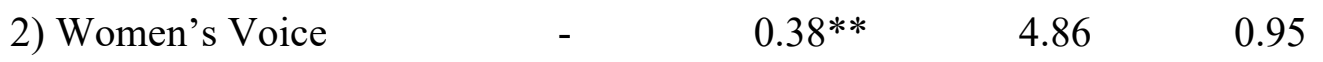




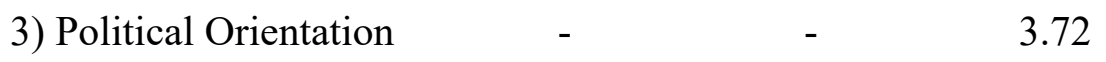

Note: ${ }^{*}$ significant at .01 level

\section{Results and Discussion}

\section{Manipulation Check}

An independent-samples t-test revealed that condition significantly affected voice, $t(94)=$ $2.17, p=.03$. Participants in the High Voice condition perceived women as having more of a voice in terms of sexual assault $(M=5.2, S D=1.3)$ than those in the Control condition $(M=4.5$, $S D=1.6)$

\section{Gender differences}

We examined gender differences in political orientation, women's voice, and men's victimization using independent samples $t$-tests. Men and women did not differ in their political orientation or in their perceptions that men are victimized $(p s>.15)$. However, men perceived women to have more voice $(M=5.3, S D=1.3)$ than women $\operatorname{did}(M=4.4, S D=1.5), \mathrm{t}(94)=$ 2.92, $p=.004$. Consistent with Study 1, gender did not moderate condition effects on victimization $^{7}$.

\section{Predictors of men's victimization}

We next regressed perceptions of men's victimization on participants' political orientation, gender, and the condition to which they were assigned (without yet estimating any interactions $)\left(F(3,92)=26.62, p<.001, R^{2}=.47\right)$. More conservative participants were more likely to perceive men as victims $(b=0.58, p<.001,95 \%$ CI $[0.44,0.71])$. Gender had no effect on perceived men's victimization $(b=-0.12, p=.65,95 \% \mathrm{CI}[-0.64,0.40])$, and experimental 
condition had a marginally significant effect on men's victimization $(b=0.47, p=.08,95 \%$ CI [$0.05,0.99])$.

\section{Political orientation as a moderator}

Using Hayes' PROCESS macro model 1, we tested whether the effect of condition on perceptions of men's victimization depended on participants' political orientation. We regressed participants' perceptions that men are victims on experimental condition (dummy coded; High Voice condition $=1$, Control condition $=0)$, their political ideology (mean-centered), and the interaction between these two predictors. We observed a marginally significant interaction between ideology and condition $(b=0.24, p=.08,95 \% \mathrm{CI}[-0.03,0.50])$. We probed the interaction despite the marginal effect given our a-priori predictions.

First, simple effects analysis revealed that conservatism predicted greater perceived victimization of men in both the High Voice $(b=0.69, p<.001,95 \%$ CI $[0.50,0.87])$ and the Control conditions $(b=0.45, p<.001,95 \%$ CI $[0.26,0.64])$. The High Voice condition strengthened the existing relationship between political orientation and the belief that men are victims. Second, we found that the effect of experimental condition depended critically on participants' political orientation. The predicted effect of the High Voice condition was significant among relatively conservative participants (i.e., one standard deviation above the mean: 5.66 on a 1-7 scale), such that those in the High Voice condition perceived more victimization than those in the Control condition $(b=0.93, p=.01,95 \%$ CI $[0.20,1.65])$. The corresponding predicted effect among relatively liberal participants (i.e., one standard deviation below the mean: 1.78 on a $1-7$ scale) was not statistically significant $(b=0.002, p=1.0,95 \% \mathrm{CI}$ $[-0.72,0.72])$. See Figure 2 . 
Figure 2. Relationship between political orientation and men's victimization by condition for Study 2.

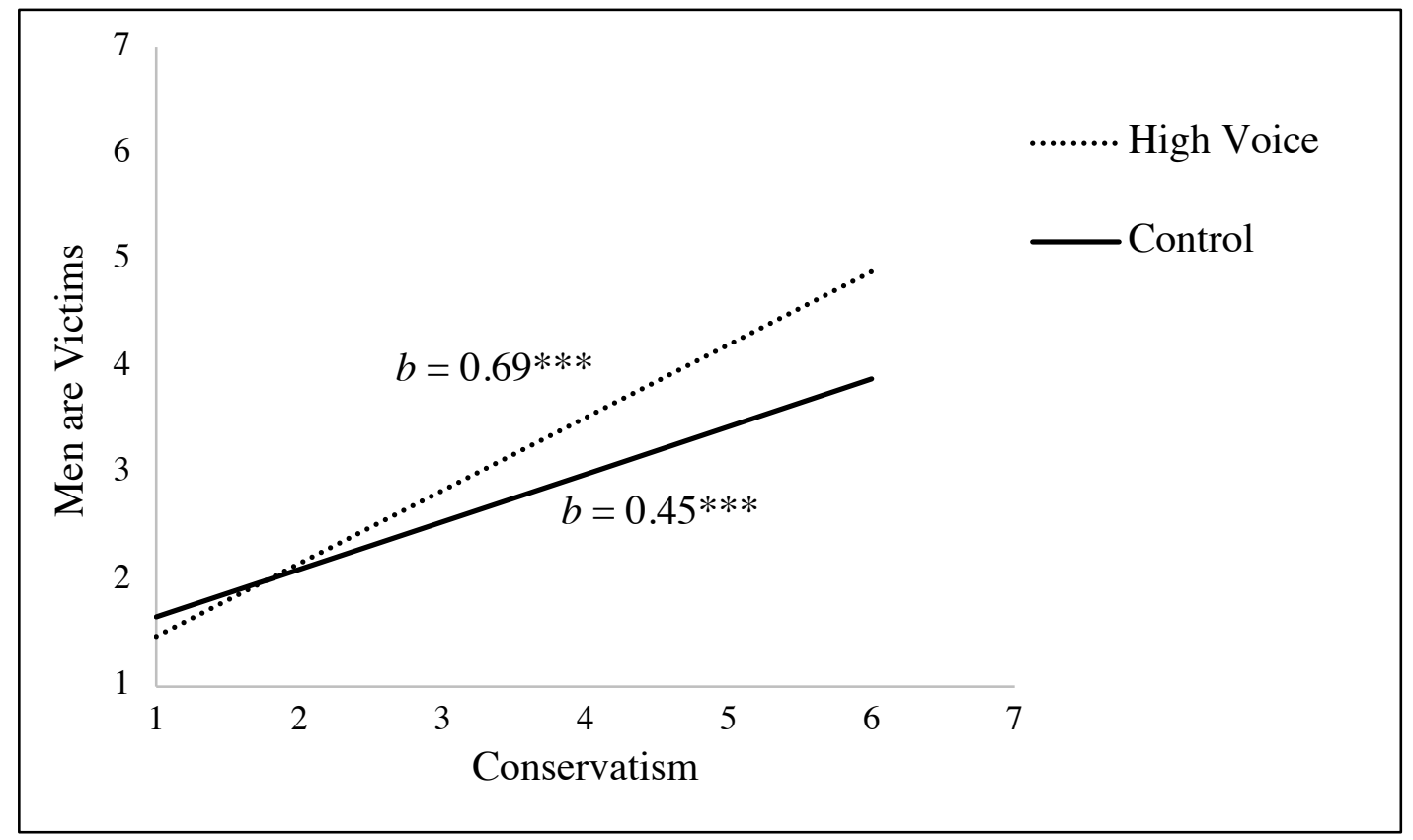

Note: $* * *$ significant at .001 . Coefficients are unstandardized. Variables are not mean-centered. Thus, values correspond to the actual points on the scale. Conservatism moderates the effect of experimental condition, but because condition is dichotomous and conservatism is continuous, we have made conservatism the $\mathrm{X}$-axis in this figure.

\section{Study 2 discussion}

Study 2 assessed whether perceiving women to have greater voice related to sexual assault increases perceptions that men are victims. We manipulated women's voice by priming participants to perceive that women's voices had been amplified by the \#MeToo movement or a control that primed only gender.

Replicating Study 1, conservatism was associated with greater perceived victimization of men. Further, although the interaction term itself was marginally significant, simple effects revealed that relatively conservative participants who read about the \#MeToo movement 
perceived significantly more victimization of men than those in the Control condition. In contrast, more liberal participants showed no condition differences.

\section{Study 3}

Studies 1 and 2 showed how increased women's voice (related to sexual assault and as amplified by the \#MeToo movement) leads both men and women, particularly more conservative individuals, to perceive men as victims. Study 3 examined the consequences of perceiving men as being victimized by the \#MeToo movement.

Prior research suggests that when high-status groups perceive themselves as victimized, they tend to support efforts to reestablish the status quo (e.g., O'Brien \& Crandall, 2005; Wilkins et al., 2015; Wilkins et al., 2018). We hypothesized that men led to believe that men are victimized would be more hesitant to work alone with a woman and less willing to combat sexual assault (relative to men in a control condition). Additionally, given evidence that conservatives are particularly motivated to maintain the status quo (e.g., Jost et al., 2003), and the relationship between attention to sexual assault and perceived men's victimization, we expected that the negative relation between men's victimization and gender-inclusive intentions would be particularly strong for more politically conservative participants.

We also explored how women react to reading about men's victimization. Given the distinct roles that men and women often occupy in the workplace and in allegations and incidents of sexual misconduct, we had men and women complete different measures. We explored women's comfort with working alone with men and women's perceptions of men's beliefs and behaviors. However, we had no strong predictions for how our manipulation would affect women's responses.

\section{Methods}




\section{Participants}

We recruited 202 White participants online through TurkPrime's Mechanical Turk Toolkit in exchange for \$1.50. Data were analyzed for 176 individuals (50.6\% women) who remained after removing those who failed attention checks and those who did not identify as heterosexual and cisgender. Participants' ages ranged from 20 to 76 years $(M=39.1, S D=12.4)$.

\section{Procedure and measures}

After consenting, participants were randomly assigned to either read a fictitious article about how the \#MeToo movement is victimizing men or a control article that described victimization of a non-self-relevant group: Canadian Inuit (see McCoy \& Major, 2007 for use of this control). Participants in the \#MeToo victimization condition read about how "men have been fired or forced to step down from high power positions, often facing jail time" and that people are worried about "a rush to judgment, unproven accusations that could destroy lives, and a bandwagon effect that could encourage people to overstate claims of sexual misconduct that ultimately hurt men.” After answering a series of attention check questions about the article, men were told to imagine they are a supervisor at a company with a team of subordinates. Women were told to imagine a close male friend or family member was a supervisor at a company with a team of subordinates. Then, participants completed the measures below. For all study materials, data and syntax, see here:

https://osf.io/fx34q/?view_only=8acff3379ce74dd2ba4da46e9cb94187. See Table 3 and 4 for $M \mathrm{~s}, S D \mathrm{~s}$, alphas, and correlations between measures for men and women participants separately. Men's preferred social distance from women. Men reported how hesitant they would be to work alone with a woman. The composite included 5 items, for instance, (1) "How hesitant 
would you be to mentor a woman?" and (2) "How hesitant would you be to travel alone with a woman you are mentoring?”.

Intent to combat sexual misconduct. Men reported how willing they would be to combat sexual assault and harassment using a 4-item composite, for instance, (1) "How willing would you be to speak out against sexual harassment in the workplace?" and (2) "How willing would you be to join a local advocacy group to support victims of sexual assault?"

Men's perceptions of women's comfort. A 5-item composite assessed how comfortable men perceive women to be working alone with a man, for instance, (1) "How comfortable do you think she would be to seek out advice from a male mentor?" and (2) "How comfortable do you think she would be to travel alone with a male supervisor?"

Women's comfort. Using a 5-item composite, women reported how comfortable they would be to work alone with a man. Items included: (1) "How comfortable would you be to seek out advice from a male mentor?" and (2) "How comfortable would you be to travel alone with a male supervisor?"

Women's perception of men's preferred social distance. Using a 5-item composite, women reported how willing they perceive a close male friend or family member to be to work alone with a woman. For instance, (1) "How hesitant do you think he would be to mentor a woman?" and (2) "How hesitant do you think he would be to travel alone with a woman he is mentoring?"

\section{Women's perceptions of men's intentions to combat sexual misconduct. Women} reported their perceptions of how willingly a close male friend or family member would combat sexual assault and harassment using a 4-item composite. Items included: (1) "How willing do 
you think he would be to attend a sexual harassment workshop at work?" and (2) "How willing do you think he would be to learn more about sexual harassment?"

Participants reported their perceptions of men's victimization and their political orientation using measures described in Study 2.

Table 3. Correlations, means, and reliabilities for measures in Study 3 for men.

\begin{tabular}{|c|c|c|c|c|c|c|}
\hline Variables & 2 & 3 & 4 & 5 & $\begin{array}{c}\text { Mean } \\
(\mathrm{SD})\end{array}$ & $\alpha$ \\
\hline $\begin{array}{l}\text { 1) Men's } \\
\text { victimization }\end{array}$ & $0.63 * *$ & $-0.27 *$ & 0.13 & $0.60 * *$ & $\begin{array}{c}3.51 \\
(1.63)\end{array}$ & 0.92 \\
\hline $\begin{array}{l}\text { 2) Men's } \\
\text { preferred social } \\
\text { distance }\end{array}$ & - & $-0.27 *$ & 0.04 & $0.46^{* *}$ & $\begin{array}{c}2.81 \\
(1.68)\end{array}$ & 0.91 \\
\hline $\begin{array}{l}\text { 3) Men's intent } \\
\text { to combat } \\
\text { sexual } \\
\text { misconduct }\end{array}$ & - & - & -0.04 & -0.21 & $\begin{array}{c}5.01 \\
(1.57)\end{array}$ & 0.87 \\
\hline $\begin{array}{l}\text { 4) Men's } \\
\text { perceptions of } \\
\text { women's } \\
\text { comfort }\end{array}$ & - & - & - & $0.22 *$ & $\begin{array}{c}3.63 \\
(1.25)\end{array}$ & 0.81 \\
\hline $\begin{array}{l}\text { 5) Political } \\
\text { orientation }\end{array}$ & - & - & - & - & $\begin{array}{c}3.40 \\
(1.79)\end{array}$ & - \\
\hline
\end{tabular}

Note: * significant at .05 level, $* *$ significant at .01 level

Table 4. Correlations, means, and reliabilities for measures in Study 3 for women.

\begin{tabular}{lllllll}
\hline Variables & 2 & 3 & 4 & 5 & $\begin{array}{c}\text { Mean } \\
\text { (SD) }\end{array}$
\end{tabular}


1) Men's

$0.24^{*}$

$0.21 *$

0.01

$0.46^{* *}$

3.10

(1.59)

0.94

victimization

2) Women's

$-0.11$

$0.23 *$

0.07

3.98

0.79

comfort

3) Women's
$-$

0.06

$0.26^{*}$

3.47

(1.56)

men's

preferred

social distance

4) Women's perception of men's intent to combat sexual misconduct

5) Political orientation

Note: * significant at .05 level, ${ }^{* *}$ significant at .01 level

\section{Results and Discussion}

\section{Manipulation Check}

We first examined whether the manipulation influenced perceptions of men's victimization. An independent-samples t-test revealed a significant effect of condition on victimization, $t(174)=2.31, p=.02,95 \% \mathrm{CI}[0.08,1.03]$, such that participants in the \#MeToo Victimization condition perceived men as being more victimized $(M=3.6, S D=1.7)$ than in the Control condition $(M=3.0, S D=1.5)$.

Because men and women completed different measures, we used separate models to predict outcome variables for men and women. We begin with the models predicting men's preferences, intentions, and beliefs. 


\section{Men: Political Orientation as a Moderator}

Using Hayes’ PROCESS macro model 1, we examined the effects of condition, political orientation and their interaction on men's preferences, intentions, and beliefs. In three separate models, we regressed men's preferred social distance from women, men's intent to combat sexual misconduct, and men's perceptions of women's comfort on experimental condition (dummy coded; High Voice condition $=1$, Control condition $=0)$, their political ideology (meancentered), and the interaction between these two predictors. When the interaction between political orientation and condition was significant, we examined the simple effects of condition among participants who were one standard deviation above (i.e., 5.19 on a 1-7 scale) and below (i.e., 1.61 on a 1-7 scale) participants' mean score of political orientation.

Men's preferred social distance from women. We first regressed men's preferred social distance from women (i.e., their hesitance to work alone with women) on our two predictors and their interaction. The interaction was significant $(b=0.39, p=.03,95 \% \mathrm{CI}[0.04$, $0.73])$.

Simple effects analysis revealed that the relation between political orientation and preferred social distance was significant for men in both conditions. However, the relationship was stronger in the \#MeToo victimization condition $(b=0.65, p<.001,95 \%$ CI $[0.40,0.91])$ than in the Control condition $(b=0.26, p=.03,95 \% \mathrm{CI}[0.03,0.50])$.

Additionally, the predicted effect of condition was larger to the extent that participants identified as conservative. Men who reported being relatively conservative were significantly more hesitant to work with women when they were assigned to the \#MeToo victimization condition than when they were assigned to the Control condition $(b=1.45, p=.001,95 \% \mathrm{CI}$ 
$[0.58,2.32])$. Men who reported being relatively liberal showed no difference in their hesitance to work with women across conditions $(b=0.06, p=.88,95 \%$ CI $[-0.80,0.93])$. See Figure 3 .

Figure 3. Relationship between political orientation and men's hesitance to work with women by condition for Study 3.

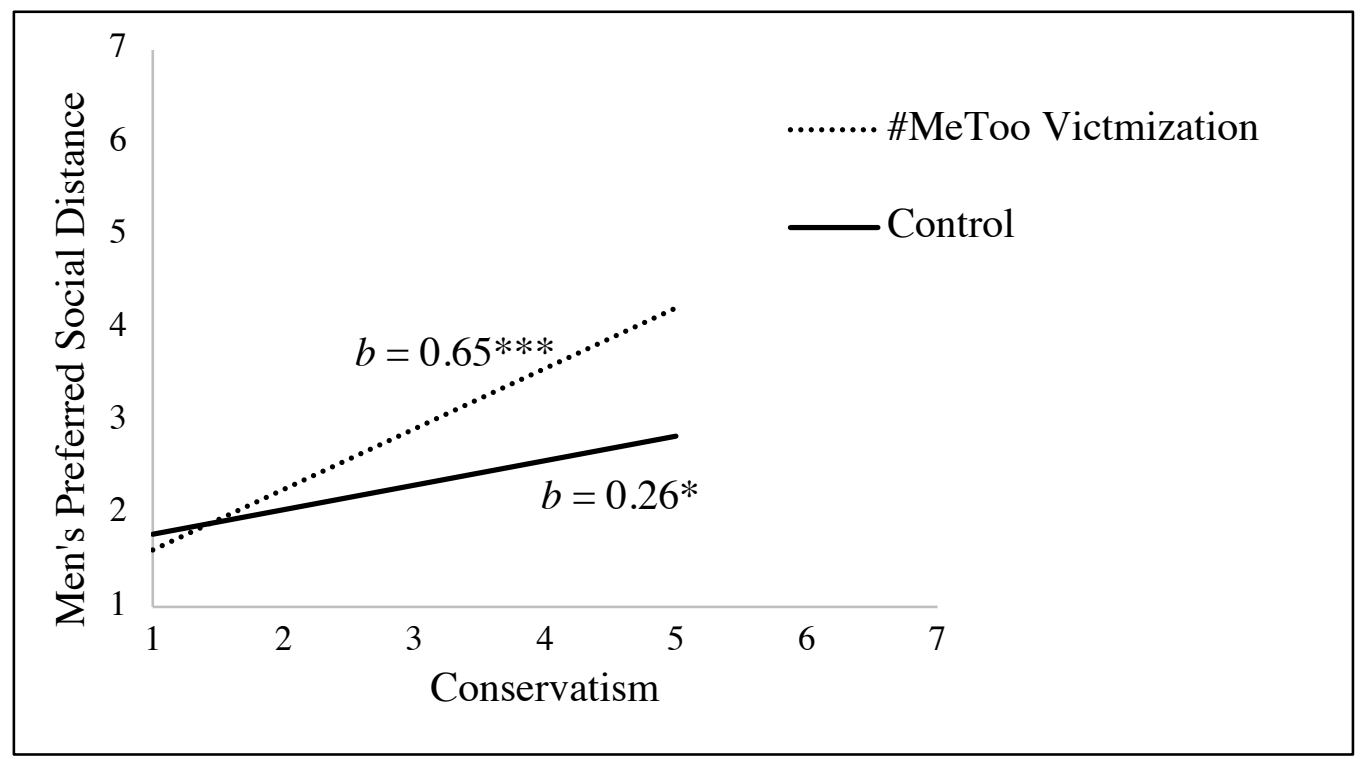

Note: * significant at .05 level, $* * *$ significant at .001 . Coefficients are unstandardized.

Variables are not mean-centered. Thus, values correspond to the actual points on the scale.

Conservatism moderates the effect of experimental condition, but because condition is

dichotomous and conservatism is continuous, we have made conservatism the X-axis in this figure.

Men's intent to combat sexual misconduct. We next regressed men's intent to combat sexual misconduct on condition, political orientation, and the interaction between them. Once again, the interaction was significant $(b=-0.41, p=.03,95 \%$ CI $[-0.78,-0.05])$.

On the one hand, ideology mattered more in the \#MeToo victimization condition than in the Control condition. Greater conservatism predicted less anti-assault and harassment advocacy 
among men in the \#MeToo victimization condition $(b=-0.41,95 \%$ CI $[-0.68,-0.14])$, but not in the Control condition $(b=0.01, p=.95,95 \%$ CI $[-0.24,0.26])$.

On the other hand, experimental condition had a stronger effect among relatively conservative participants than among relatively liberal participants. Once again, the model predicted no difference in relatively liberal men's intent to combat sexual misconduct across conditions $(b=0.65, p=.17,95 \%$ CI $[-0.27,1.58])$. However, relatively conservative men in the \#MeToo victimization condition reported marginally less activist intentions than they did in the Control condition $(b=-0.83, p=.08,95 \%$ CI $[-1.76,0.10])$. See Figure 4.

Figure 4. Relationship between political orientation and men's activism by condition for Study 3.

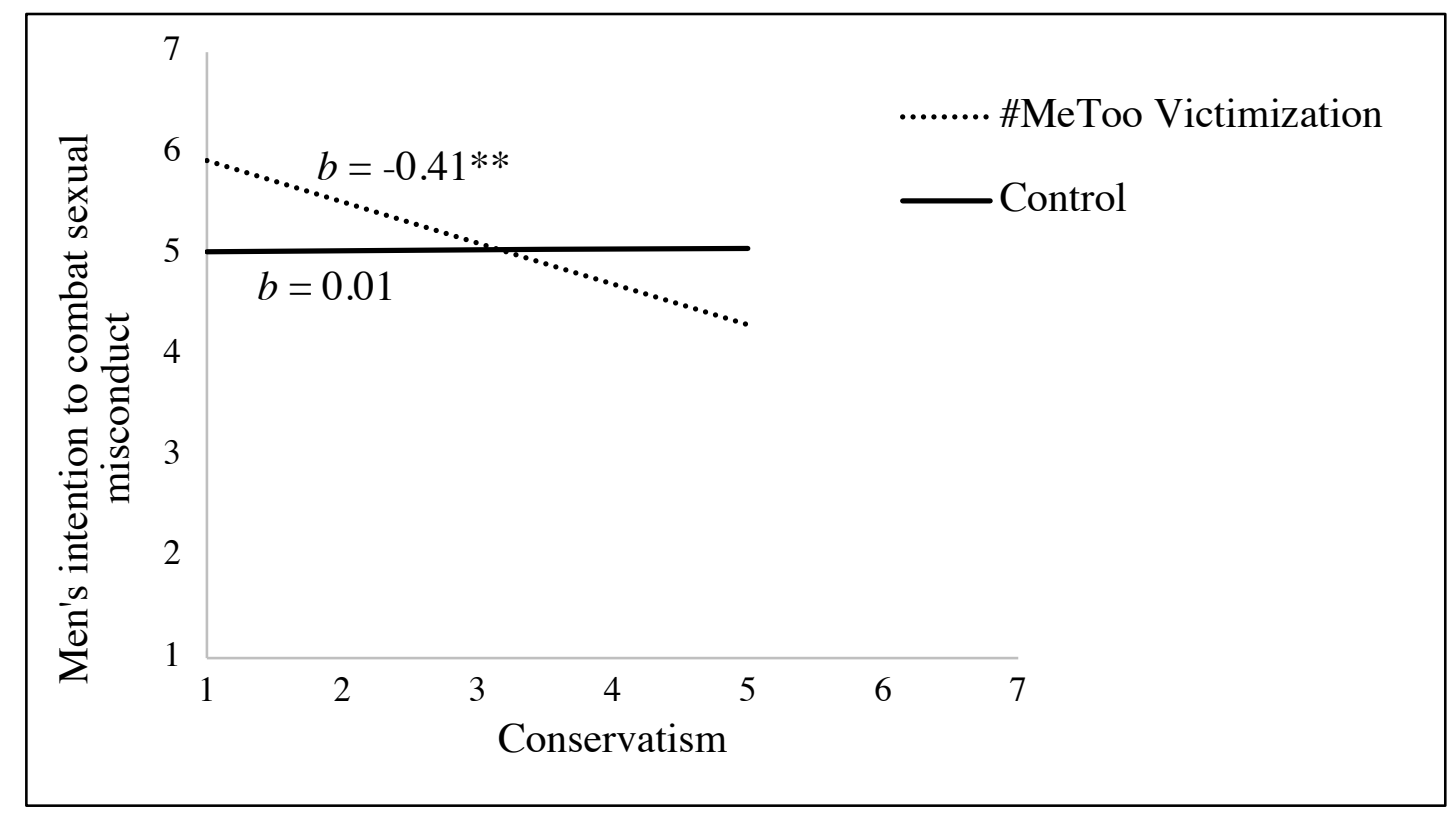

Note: ** significant at .01 level. Coefficients are unstandardized. Variables are not meancentered. Thus, values correspond to the actual points on the scale. Conservatism moderates the effect of experimental condition, but because condition is dichotomous and conservatism is continuous, we have made conservatism the $\mathrm{X}$-axis in this figure. 
Men's perceptions of women's comfort. Finally, we used political orientation, experimental condition, and the interaction between them to predict men's perceptions of how comfortable women are when working alone with men. Again, condition and political orientation interacted as predicted $(b=0.30, p=.04,95 \%$ CI $[0.01,0.59])$.

Once again, ideology mattered more in the \#MeToo victimization condition than in the Control condition. When men were asked how comfortable they thought women would be working alone with men, relatively liberal men in the \#MeToo victimization condition tended to perceive women would be less comfortable than did relatively conservative men $(b=0.32, p=$ $.004,95 \%$ CI $[0.10,0.53])$. Political orientation had no effect in the Control condition $(b=0.01$, $p=.90,95 \%$ CI $[-0.18,0.21])$.

In contrast to our prior results, though, experimental condition had a stronger effect among relatively liberal participants than among relatively conservative participants. Relatively conservative men's perceptions of women's comfort did not differ based on condition $(b=0.25$, $p=.50,95 \%$ CI $[-0.48,0.98])$; however, relatively liberal men's perceptions of women's comfort were significantly lower in the \#MeToo victimization condition than in the Control condition (b $=-0.84, p=.02,95 \%$ CI $[-1.57,-0.11])$. See Figure 5 .

Figure 5. Relationship between political orientation and men's perceptions of women's comfort by condition for Study 3.

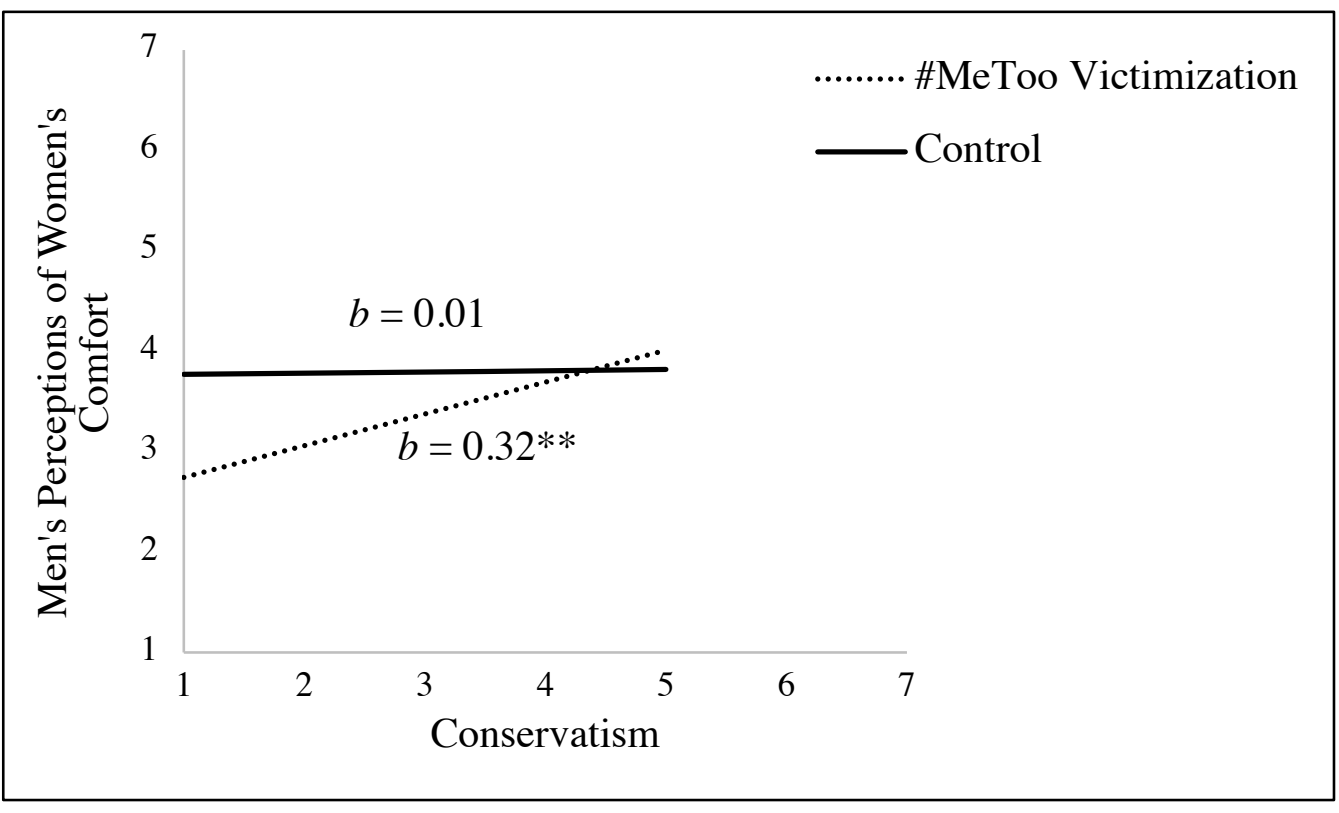


Note: ** significant at .01 level. Coefficients are unstandardized. Variables are not meancentered. Thus, values correspond to the actual points on the scale. Conservatism moderates the effect of experimental condition, but because condition is dichotomous and conservatism is continuous, we have made conservatism the $\mathrm{X}$-axis in this figure.

\section{Women: Political Orientation}

Neither condition nor political orientation were related to women's comfort, women's perceptions of men's preferred social distance at work, or women's perceptions of men's intentions to combat sexual misconduct $(p s>.14)$.

\section{Study 3 discussion}

Taken together, our findings suggest that relatively conservative men who read an article arguing that the \#MeToo movement has victimized men tended to report wanting to distance themselves from women and from efforts to combat sexual misconduct. Conservatism predicted men's hesitancy to work alone with a woman, their reluctance to fight against sexual misconduct, and their perception that women are comfortable working alone with men.

One could argue that relatively conservative men were more hesitant to work alone with women in the workplace because of a new concern for women's comfort in light of the \#MeToo movement. However, relatively conservative participants in the \#MeToo victimization condition did not report any more concern about women's comfort than relative conservatives in the Control condition. They also reported being less (not more) likely to try to combat sexual assault and harassment than relatively conservative men in the Control condition.

Our findings are more consistent with the possibility that considering \#MeToo made relatively conservative men in our study more hesitant to work closely with women out of fear that they might be victimized as a result of those interactions. In contrast, the fact that relatively 
liberal men who read about men's victimization perceived women as less comfortable in the workplace could explain why relatively liberal men reported greater intentions to combat sexual misconduct. That is, relatively liberal men in the \#MeToo victimization condition seemed to express more sensitivity to women's potential discomfort and more willingness to engage in activism on their behalf.

Neither condition nor political orientation predicted women's comfort, their perceptions of men's preferred social distance at work, or their perceptions that men will combat sexual misconduct. This could be because women were asked to imagine how another group would respond to a situation - a more psychologically distant hypothetical situation. Alternatively, women's expectations for men's behavior may be more difficult to influence than men's professed intentions toward women.

\section{General Discussion}

Our goal in the present studies was to explain backlash against the \#MeToo movement. Faced with a movement intended to raise awareness of the ubiquity of sexual assault and to empower victims to seek justice, some instead perceive a threat to innocent men. We wanted to know who perceives this threat and why.

Prior theory suggests competing predictions as to whether gender or political orientation would be a greater predictor. For instance, some research suggests that men, given their relative advantage in society, may respond negatively to the \#MeToo movement to the extent that they perceive it as a potential threat to their social advantage. On the other hand, another body of work suggests that attitudes toward social change may be more closely tied to people's endorsement of ideologies that justify existing social structures (i.e., political conservatism) than to their own position within the hierarchy (in this case gender). 
We find that people's reactions to the \#MeToo movement depend on both their political orientation and their gender, but the effect of political orientation was especially robust across studies. Consistent with evidence that conservatives in the contemporary U.S. tend to oppose social change and favor the perpetuation of longstanding status hierarchies (Jost et al., 2009), more conservative participants in our studies were more likely than relatively liberal participants to perceive the \#MeToo movement and women's growing voice on issues of sexual assault as a threat that victimizes men. This difference is relative; in Study 1, we found that both relatively conservative and relatively liberal individuals tended to conflate women's empowerment with potential costs for men. This suggests that even liberals may sometimes see women's empowerment as hurting men. However, across all three studies, we observe that conservativism predicts more negative reactions. For instance, in Study 2, although the interaction term was marginally significant, simple slopes revealed that among relatively conservative participants, those who read about the \#MeToo movement perceived significantly more victimization of men than those in the control condition. People whose worldview favors the status quo, and the gendered hierarchies that comprise it, seem more likely to perceive that men are harmed by \#MeToo.

The effects we found for gender were weaker and less robust than those of political orientation, but men and women did display some differences. In both Studies 1 and 2, men were more concerned than women were with men's victimization, and men also tended to say that women had more voice than women themselves believed they had. In Study 3, we found that priming participants to perceive that men were being victimized only affected the outcomes we observed for men. However, this last result should be interpreted with caution given that men and women responded to different questions. 
Reading about \#MeToo as victimizing men may have motivated men in our study to distance themselves from women in the workplace, perhaps to protect themselves from potential "victimization." We found no evidence that this hesitance to work closely with women was grounded in a concern for women's comfort or wellbeing. On the contrary, men's reluctance to work with women would likely deprive women of valued opportunities and resources, especially in male-dominated professions. This result is consistent with practices in the real world. For instance, men who follow the so-called "Billy Graham Rule" (a practice among some evangelical men) intentionally avoid spending time alone with women who are not their wife so as to avoid sexual temptation and avoid accusations of sexual harassment or assault (Hesse, 2019). While practices like these may sometimes be construed as a way to "protect" women, they presume that any one-on-one interaction between men and women is at least potentially sexual and that the presumed risk of (men's) sexual temptation outweighs other reasons opposite-sex individuals might interact as friends or colleagues. This outlook can severely disadvantage women in workplaces with male leadership. To put this in context using a high-profile example, former Vice President Mike Pence publicly claimed that he refused to be alone with women (The Guardian, 2017). The fact that women cannot take advantage of business dinners or career advice over lunch with some men might have dire consequences for women's career advancement. Men's hesitance to interact with women may deprive women of their seat at the table.

We set out to determine who perceives the \#MeToo movement to be a threat to men and how that perception might impact women's lives. We find that it is largely (but not exclusively) relatively conservative people who perceive the \#MeToo movement as threatening and that gender is a less important predictor of this perception. Thus, despite the movement's stated goal to empower women, women who strongly endorse conservative ideologies may abet 
conservative men in resisting the changes it advocates. The quotation from Laura Loomer with which we begin our paper is an anecdotal testament to this possibility.

That said, how men behave when they hold these negative beliefs about the \#MeToo movement might have an especially strong impact on women's professional opportunities. Relatively conservative men led to believe that men's status in American society is precarious said they would change their behavior in ways that could isolate and disadvantage the women with whom they work. Neither relatively liberal men nor women (of any political orientation) showed the same reaction. So, although political orientation seems to shape what people believe about the \#MeToo movement, their gender seems to determine what they do about that belief, sometimes producing behavior that could undermine or even reverse the very advances the \#MeToo movement aims to make.

\section{Limitations and Future Directions}

One limitation of our studies is that they rely on self-report questionnaires. Men (especially relatively liberal men) may overstate their willingness to work with women or their inclination toward feminist activism if they perceive these progressive characteristics as socially desirable. Our reliance on behavioral intentions may therefore overestimate ideological differences and underestimate men's willingness to discriminate against women. Future studies using behavioral measures could cast more light on the real-world consequences of how men react to the \#MeToo movement. Does a perceived threat to men's power and status affect actual promotion and hiring decisions? Or how often or how effectively men work together with women in teams? These questions remain open to future investigation.

We also focused specifically and intentionally on the negative reactions that people can have to the \#MeToo movement, rather than its real and potential positive effects for women and 
society. The hashtag and the climate it has created have provided women the opportunity to express themselves, feel heard, and find validation in others' experiences (Grewal Law PLLC, 2020). Moreover, the movement may have helped to change men's behavior toward women in socially desirable ways: perhaps making them more intentional and considerate in how they interact with women in their daily lives. Our goal is not to make normative claims about the desirability of the \#MeToo movement or the strategies it has employed. Rather, we seek to highlight and explain the roots of some individuals' defensive reactions to the movement and their resistance to the change it attempts to effect.

\section{Conclusion}

Sexual assault remains an important and pervasive social ill. The \#MeToo movement has attempted to grapple with this issue and made strides in helping women to report sexual assault (Levy \& Mattsson, 2020), creating more gender equality in workplaces (Carlsen et al., 2018). Even so, the \#MeToo movement has met with considerable resistance from those concerned that it has gone too far. We show that this resistance is closely related to political ideologies that treasure the (inegalitarian) status quo over the risk and uncertainty that would accompany systemic change. We also show that this defensive reaction to the threat of change could manifest in men's behaviors in ways that, ironically, exacerbate existing gender inequalities. 


\section{References}

Alter, C. (2017, December 6). Democrats are more likely to believe sexual assault accusations. Time. https://time.com/5049665/republicans-democrats-believe-sexual-assault-accusations-survey/

Anderson, C. (2016). White rage: The unspoken truth of our racial divide. Bloomsbury Publishing USA.

Anderson, M., \& Toor, S. (2018, October 11). How social media users have discussed sexual harassment since \#MeToo went viral. Pew Research Center. https://www.pewresearch.org/facttank/2018/10/11/how-social-media-users-have-discussed-sexual-harassment-since-metoo-wentviral/

Björklund, J., \& Dahl, U. (2017). On queer funding, \#metoo, and giving gay people a bad name. Lambda Nordica, 22(4), 7-13.

Black, M.C., Basile, K.C., Breiding, M.J., Smith, S.G., Walters, M.L., Merrick, M.T., Chen, J., \& Stevens, M.R. (2011). The national intimate partner and sexual violence survey (NISVS): 2010 summary report. Atlanta, GA: National Center for Injury Prevention and Control, Centers for Disease Control and Prevention.

Bobo, L. D. (1999). Prejudice as group position: Microfoundations of a sociological approach to racism and race relations. Journal of Social Issues, 55(3), 445-472. https://doi.org/10.1111/00224537.00127

Bobo, L., \& Hutchings, V. L. (1996). Perceptions of racial group competition: Extending Blumer's theory of group position to a multiracial social context. American Sociological Review, 61(6), 951-972. JSTOR. https://doi.org/10.2307/2096302

Burke, T. (2017, November 9). Perspective | \#MeToo was started for black and brown women and girls. They're still being ignored. Washington Post. https://www.washingtonpost.com/news/post- 
nation/wp/2017/11/09/the-waitress-who-works-in-the-diner-needs-to-know-that-the-issue-ofsexual-harassment-is-about-her-too/

Carlsen, A., Salam, M., Cain Miller, C., Lu, D., Ngu, A., Patel, J. K., \& Wichter, Z. (2018, October 29). \#MeToo brought down 201 powerful men. Nearly half of their replacements are women. The New York Times. https:/www.nytimes.com/interactive/2018/10/23/us/metoo-replacements.html

Costa, M., Briggs, T., Chahal, A., Fried, J., Garg, R., Kriz, S., Lei, L., Milne, A., \& Slayton, J. (2020). How partisanship and sexism influence voters' reactions to political\# MeToo scandals. Research \& Politics, 7(3), 2053168020941727. https://doi.org/10.1177/2053168020941727

Clark, L. M., \& Lewis, D. J. (1977). Rape: The price of coercive sexuality. Toronto: Women's Press.

Craig, M. A., \& Richeson, J. A. (2017). Information about the US racial demographic shift triggers concerns about anti-White discrimination among the prospective White "minority." PLOS ONE, 12(9), e0185389. https://doi.org/10.1371/journal.pone.0185389

Craig, M. A., \& Richeson, J. A. (2014). More diverse yet less tolerant? How the increasingly diverse racial landscape affects White Americans' racial attitudes. Personality and Social Psychology Bulletin, 40(6), 750-761. https://doi.org/10.1177/0146167214524993

Diamond, J. (2018, October 2) Trump says it's 'a very scary time for young men in America'. CNN Politics. https://www.cnn.com/2018/10/02/politics/trump-scary-time-for-young-menmetoo/index.html

Division of Violence Prevention. Findings from the national intimate partner and sexual violence survey: 2010-2012 state report. (n.d.). National Center for Injury Prevention and Control. CDC. https://www.cdc.gov/violenceprevention/pdf/NISVS-StateReportFactsheet.pdf 
Dixon, J., Levine, M., Reicher, S., \& Durrheim, K. (2012). Beyond prejudice: Are negative evaluations the problem and is getting us to like one another more the solution? Behavioral and Brain Sciences, 35(6), 411-425. https://doi.org/10.1017/S0140525X11002214

Easley, J. (2018, February 26). Poll: Voters want Trump to do more to address violence against women [Text]. TheHill. https://thehill.com/homenews/administration/375628-poll-voters-say-trump-notdoing-enough-to-address-violence-against

Eidelman, S., \& Crandall, C. S. (2012). Bias in favor of the status quo: Bias and the status quo. Social and Personality Psychology Compass, 6(3), 270-281. https://doi.org/10.1111/j.17519004.2012.00427.x

Ferguson, C. E., \& Malouff, J. M. (2016). Assessing police classifications of sexual assault reports: A meta-analysis of false reporting rates. Archives of Sexual Behavior, 45(5), 1185-1193. https://doi.org/10.1007/s10508-015-0666-2

Goh, J. X., Bandt-Law, B., Cheek, N. N., Sinclair, S., \& Kaiser, C. R. (2021). Narrow prototypes and neglected victims: Understanding perceptions of sexual harassment. Journal of Personality and Social Psychology. Advance online publication. https://doi.org/10.1037/pspi0000260

Grace, S., Lloyd, C., \& Smith, L. J. (1992). Rape: From recording to conviction. London: Home Office. Grewal Law PLLC. (2020, June 9). How the \#MeToo Movement Gave a Voice to Many. https://www.4grewallaw.com/blog/2020/june/how-the-metoo-movement-gave-a-voice-to-many/ Hayes, A. F. (2017). Introduction to mediation, moderation, and conditional process analysis, Second Edition: A Regression-Based Approach. Guilford Publications.

Hesse, M. (2019). Commentary: The 'Billy Graham rule' doesn't honor your wife - it demeans her and all women. https://www.chicagotribune.com/opinion/commentary/ct-opinion-billy-graham-rulemississippi-governor-candidate-20190711-wbpifhmipjez5lfh6wp3msai4i-story.html 
Horowitz, J.M., Parker, K., Stepler, R. (2017). Wide partisan gaps in U.S. over how far the country has come on gender equality. Pew Research Center. Social and Demographic Trends. https://www.pewresearch.org/social-trends/2017/10/18/wide-partisan-gaps-in-u-s-over-how-farthe-country-has-come-on-gender-equality/

Ipsos/NPR Examine views on sexual harassment and assault. (2018, October 31). Ipsos. https://www.ipsos.com/en-us/news-polls/NPR-Sexual-Harassment-and-Assault

Jackman, M. R. (1994). The velvet glove: Paternalism and conflict in gender, class, and race relations. Berkeley: University of California Press.

Jost, J. T., \& Banaji, M. R. (1994). The role of stereotyping in system-justification and the production of false consciousness. British Journal of Social Psychology, 33(1), 1-27. https://doi.org/10.1111/j.2044-8309.1994.tb01008.x

Jost, J. T., \& Burgess, D. (2000). Attitudinal ambivalence and the conflict between group and system justification motives in low status groups. Personality and Social Psychology Bulletin, 26(3), 293-305. https://doi.org/10.1177/0146167200265003

Jost, J. T., \& Hunyady, O. (2005). Antecedents and consequences of system-justifying ideologies. Current Directions in Psychological Science, 14(5), 260-265. https://doi.org/10.1111/j.09637214.2005.00377.x

Jost, J. T., \& Hunyady, O. (2002). The psychology of system justification and the palliative function of ideology. European Review of Social Psychology, 13, 111-153. https://www.psych.nyu.edu/newsbox/PsychologySystemJustification.pdf

Jost, J. T., \& Major, B. (2001). The psychology of legitimacy: Emerging perspectives on ideology, justice, and intergroup relations. Cambridge University Press. 
Jost, J. T., \& Kende, A. (2020). Setting the record straight: System justification and rigidity-of-the-right in contemporary Hungarian politics. International Journal of Psychology, 55(S1), 96-115. https://doi.org/10.1002/ijop.12631

Jost, J. T., Krochik, M., Gaucher, D., \& Hennes, E. P. (2009). Can a psychological theory of ideological differences explain contextual variability in the contents of political attitudes? Psychological Inquiry, 20(2-3), 183-188. https://doi.org/10.1080/10478400903088908

Jost, J. T., Kruglanski, A. W., Glaser, J., \& Sulloway, F. J. (2003). Political conservatism as motivated social cognition. Psychological Bulletin, 129(3), 339-375. https://doi.org/10.1037/00332909.129.3.339

Jost, J. T., Nosek, B. A., \& Gosling, S. D. (2008). Ideology: Its resurgence in social, personality, and political psychology. Perspectives on Psychological Science, 3(2), 126-136. https://doi.org/10.1111/j.1745-6916.2008.00070.x

Kaiser, C. R., Hagiwara, N., Malahy, L. W., \& Wilkins, C. L. (2009). Group identification moderates attitudes toward ingroup members who confront discrimination. Journal of Experimental Social Psychology, 45(4), 770-777. https://doi.org/10.1016/j.jesp.2009.04.027

Kearl, H. (2018). The Facts Behind the \#metoo Movement: A National Study on Sexual Harassment and Assault. Stop Street Harassment, Raliance, and UC San Diego Center on Gender Equity and Health. http://www.stopstreetharassment.org/wp-content/uploads/2018/01/Full-Report-2018National-Study-on-Sexual-Harassment-and-Assault.pdf

Kilpatrick, D. G., Resnick, H. S., Ruggiero, K. J., Conoscenti, L. M., \& McCauley, J. (2007). Drugfacilitated, incapacitated, and forcible rape: A national study. (Report by Medical University of South Carolina). Charleston, SC: National Crime Victims Research \& Treatment Center. 
Kuchynka, S. L., Bosson, J. K., Vandello, J. A., \& Puryear, C. (2018). Zero-sum thinking and the masculinity contest: Perceived intergroup competition and workplace gender bias. Journal of Social Issues, 74(3), 529-550. https://doi.org/10.1111/josi.12281

Kulik, L. (2018). Explaining egalitarianism in gender-role attitudes. Asian Women, 34(2), 61-87. https://doi.org/10.14431/aw.2018.06.34.2.61

Lambert, A. J., \& Raichle, K. (2000). The role of political ideology in mediating judgments of blame in rape victims and their assailants: A test of the just world, personal responsibility, and legitimization hypotheses. Personality and Social Psychology Bulletin, 26(7), 853-863. https://doi.org/10.1177/0146167200269010

Lerner, M. J. (1980). The belief in a just world. I MJ Lerner (Red.). The Belief in a Just World, 9-30. https://doi.org/10.1007/978-1-4899-0448-5_2

Leung, R., \& Williams, R. (2019). \#MeToo and intersectionality: An examination of the \#MeToo movement through the R. Kelly scandal. Journal of Communication Inquiry, 43(4), 349-371. https://doi.org/10.1177/0196859919874138

Levy, R., \& Mattsson, M. (2020). The effects of social movements: Evidence from \#MeToo (SSRN Scholarly Paper ID 3496903). Social Science Research Network. https://doi.org/10.2139/ssrn.3496903

Lucarini, A., Suitner, C., Brown, R., Craig, M. A., Knowles, E. D., \& Salvador Casara, B. G. (2020). The \#MeToo late effect: Victim blame and trust denial for sexual harassment not immediately reported. Personality and Individual Differences, 167, 110240. https://doi.org/10.1016/j.paid.2020.110240 
MacKinnon, C., A. (2019, March 24). Where \#MeToo came from, and where it's going. The Atlantic. https://www.theatlantic.com/ideas/archive/2019/03/catharine-mackinnon-what-metoo-haschanged/585313/

Marshall, W. P. (1986). Discrimination and the right of association. Northwestern University Law Review, 81(1), 68-88..

McCoy, S. K., \& Major, B. (2007). Priming meritocracy and the psychological justification of inequality. Journal of Experimental Social Psychology, 43(3), 341-351. https://doi.org/10.1016/j.jesp.2006.04.009

Mebane, M. E., Aiello, A., \& Francescato, D. (2020). Political Gender Gap and Social Dominance Orientation. In Sexual Ethics. IntechOpen.

Morgan, R. E., Kena, G. (2018). Criminal victimization, 2016: Revised. Bureau of Justice Statistics. https://www.bjs.gov/content/pub/pdf/cv16.pdf

Moshinsky, A., \& Bar-Hillel, M. (2010). Loss aversion and status quo label bias. Social Cognition, 28(2), 191-204. https://doi.org/10.1521/soco.2010.28.2.191

North, A. (2018, October 10). \#HimToo, the online movement spreading myths about false rape allegations, explained. Vox. https://www.vox.com/policy-andpolitics/2018/10/10/17957126/himtoo-movement-pieter-hanson-tweet-me-too

O’Brien, L. T., \& Crandall, C. S. (2005). Perceiving self-interest: Power, ideology, and maintenance of the status quo. Social Justice Research, 18(1), 1-24. https://doi.org/10.1007/s11211-005-3368-4

Onwuachi-Willig, A. (2018). What about \#Ustoo?: The Invisibility of Race in the \#Metoo Movement. The Yale Law Journal Forum. https://racism.org/articles/intersectionality/gender/2146-whatabout-ustoo-the-invisibility-of-race-in-the-metoo-movement 
Patton, T. O., \& Snyder-Yuly, J. (2007). Any four Black men will do: Rape, race, and the ultimate scapegoat. Journal of Black Studies, 37(6), 859-895. https://doi.org/10.1177/0021934706296025

Pew Research Center. (2018). Wide gender gap, growing educational divide in voters' party identification. U.S. Politics and Policy.

RAINN. (n.d.). Perpetrators of sexual violence: Statistics. Retrieved November 15, 2019, from https://www.rainn.org/statistics/perpetrators-sexual-violence

Pflum, M. (2018, October 15). A year ago, Alyssa Milano started a conversation about \#MeToo. These women replied. NBC News. https://www.nbcnews.com/news/us-news/year-ago-alyssa-milanostarted-conversation-about-metoo-these-women-n920246

Rennison, C. M. (2002). Rape and sexual assault: Reporting to police and medical attention, 1992-2000: (387542004-001) [Data set]. American Psychological Association. https://doi.org/10.1037/e387542004-001

Safronova, V., \& Halleck, R. (2019, May 23). These rape victims had to sue to get the police to investigate. The New York Times. https://www.nytimes.com/2019/05/23/us/rape-victims-kitspolice-departments.html

Smith, S., Zhang, X., Basile, K.C., Merrick, M., Wang, J., Kresnow, M., \& Chen, J. (2015). National intimate partner and sexual violence survey: 2015 data brief. Violence Prevention. CDC. Retrieved April 1, 2021 from: https://www.cdc.gov/violenceprevention/datasources/nisvs/2015NISVSdatabrief.html

Sidanius, J., Levin, S., Federico, C. M., \& Pratto, F. (2001). Legitimizing ideologies: The social dominance approach. In J. T. Jost \& B. Major (Eds.), The psychology of legitimacy: Emerging perspectives on ideology, justice, and intergroup relations (p. 307-331). Cambridge University Press. 
Sidanius, J., \& Pratto, F. (1999). Social dominance: An intergroup theory of social hierarchy and oppression. Cambridge University Press.

Unzueta, M. M., Everly, B. A., \& Gutiérrez, A. S. (2014). Social dominance orientation moderates reactions to Black and White discrimination claimants. Journal of Experimental Social Psychology, 54, 81-88. https://doi.org/10.1016/j.jesp.2014.04.005

Ullman, S. E. (2010). Psychology of women (APA Division 35). Talking about sexual assault: Society's response to survivors. American Psychological Association. https://doi.org/10.1037/12083-000

van der Linden, S., \& Panagopoulos, C. (2019). The O’Reilly factor: An ideological bias in judgments about sexual harassment. Personality and Individual Differences, 139, 198-201. https://doi.org/10.1016/j.paid.2018.11.022

Wilkins, C. L., \& Kaiser, C. R. (2014). Racial progress as threat to the status hierarchy: Implications for perceptions of anti-White bias. Psychological Science, 25(2), 439-446. https://doi.org/10.1177/0956797613508412

Wilkins, C. L., Wellman, J. D., Babbitt, L. G., Toosi, N. R., \& Schad, K. D. (2015). You can win but I can't lose: Bias against high-status groups increases their zero-sum beliefs about discrimination. Journal of Experimental Social Psychology, 57, 1-14. https://doi.org/10.1016/j.jesp.2014.10.008

Wilkins, C. L., Wellman, J. D. \& Kaiser, C. R. (2013). Status legitimizing beliefs increase positivity toward Whites who claim anti-White bias. Journal of Experimental Social Psychology, 49, 1114-1119. DOI: 10.1016/j.jesp.2013.05.017

Wilkins, C. L., Wellman, J. D., Flavin, E. L., \& Manrique, J. A. (2018). When men perceive anti-male bias: Status-legitimizing beliefs increase discrimination against women. Psychology of Men \& Masculinity, 19(2), 282. https://doi.org/10.1037/men0000097 
Wilkins, C. L., Wellman, J. D., \& Schad, K. D. (2017). Reactions to anti-male sexism claims: The moderating roles of status-legitimizing belief endorsement and group identification. Group Processes \& Intergroup Relations, 20(2), 173-185. https://doi.org/10.1177/1368430215595109

Wyatt, G. E. (1992). The Sociocultural Context of African American and White American Women's Rape. Journal of Social Issues, 48(1), 77-91. https://doi.org/10.1111/j.15404560.1992.tb01158.x 


\section{Notes}

$1 \quad$ Data for all studies were collected between December 2018 and December 2019.

2 We included 4 attention checks (e.g. asking participants to choose a particular number of the scale).

3 We excluded non-heterosexual participants because egalitarian values differ based on sexual orientation (Kulik, 2018). Additionally, the conversation around the \#MeToo movement has largely been in regard to sexual assault committed by straight men (Björklund \& Dahl, 2017). However, we ran analyses including non-heterosexual participants and found the same pattern of results.

4 As the \#Metoo movement has particularly highlighted the plight of White victims (Burke, 2017; Leung \& Williams, 2019; Onwuachi-Willig, 2018), we restrict our sample to Whites. White people and people of color do not have the same history with accusations of rape. Whereas White men accused often go unpunished, Black men have historically been falsely accused and convicted of rape (Wyatt, 1992; Patton \& Snyder-Yuly, 2007). Therefore, people of color may perceive the \#MeToo movement differently than Whites. Due to these factors, we restricted our sample to White people in Studies 2 and 3.

$5 \quad$ In a third condition (not reported here) participants read that women's voice related to sexual assault has decreased (low voice condition). We excluded the condition from analyses because it did not successfully lower perceptions of women's voice (compared to the high voice condition) based on the manipulation check. This is likely because reading about the \#MeToo movement was sufficient to increase perceived women's voice. Therefore, we focus on the control condition which primes gender but does not mention voice or the movement. See supplemental materials for analyses including this third condition: https://osf.io/xdaws/?view_only=01fda47b51214553aa01a500d85f2746.

6 The new victimization measure was broader than the one used in Study 1, as we wanted to examine perceptions that men are victimized in general (not just by allegations of sexual assault). See supplemental materials for analysis using the more specific victimization measure (victimization in terms of sexual assault):

https://osf.io/xdaws/?view_only=01fda47b51214553aa01a500d85f2746.

7 For victimization there was a main effect of condition, $b=0.73, p=.04$, CI [0.04, 1.41], but no main effect gender, $b=-0.18, p=.72$, CI $[-1.15,0.80]$. Furthermore, there was no interaction between condition and gender, $b=0.72, p=.30$, CI $[-0.65,2.08]$. 